\title{
Aplasia cutis congenita and amniotic band syndrome: an uncommon association
}

\author{
Joana Pimenta, ${ }^{1}$ Patrícia Lapa, ${ }^{1}$ Lina Ramos ${ }^{2}$
}

Department of Neonatology, Maternidade Dr Daniel de Matos-Centro Hospitalar e Universitário de Coimbra, Coimbra, Portugal

${ }^{2}$ Pediatric Hospital of Coimbra, Coimbra, Portugal

\section{Correspondence to}

Dr Joana Pimenta, joanafmp@gmail.com

Accepted 14 January 2017
CrossMark

\begin{tabular}{l}
\hline To cite: Pimenta J, Lapa P, \\
Ramos L. BMJ Case Rep \\
Published online: [please \\
include Day Month Year] \\
doi:10.1136/bcr-2016- \\
218950
\end{tabular}

To cite: Pimenta J, Lapa $P$, Ramos L. BMJ Case Rep Published online: [please 218950

\section{DESCRIPTION}

Amniotic band syndrome is an unusual clinical entity with a wide variety of presentations that include constriction rings, syndactyly and limb or digital amputations. ${ }^{1}{ }^{2}$ Aplasia cutis congenita is a rare congenital anomaly involving variant layers of the skin, most commonly affecting the scalp. ${ }^{3}$ Amniotic bands following rupture of the amniotic membrane in early pregnancy have been proposed as a cause of aplasia cutis congenita. ${ }^{3}$ Still, the presence of a fibrous amniotic band at the site of the constriction ring at birth is extremely unusual. This case further adds to the evidence of amniotic bands as aetiology for constriction rings and aplasia cutis.

A full-term female neonate was delivered by caesarean section as a result of non-progressive labour. The pregnancy had been uneventful and there was no remarkable family history. Physical examination at birth showed several constriction rings around both hands and feet, mostly affecting the digits and toes. All the distal phalanges of the right hand were involved (figure 1) and there was syndactyly of the 2nd and 3rd toes of the left foot (figure 2). There were no signs of limb perfusion abnormalities and there was no neurological deficit (motor and sensitive). A band of dark inelastic fibrous material was present within the constriction areas of the right hand (figure 1). Scalp examination revealed five well-demarcated, non-inflammatory, oval lesions, the largest with $\sim 25 \mathrm{~mm}$, involving the epidermis



Figure 1 Right hand showing constriction rings with persistent dark fibrous band around fingers digits, associated with distal partial autoamputation.



Figure 2 Left foot with distal phalanges malformations and syndactyly between the 2nd and 3rd toes.

and the upper dermis (figure 3). The remainder of the physical examination was normal. Posterior investigation, namely transfontanelar ultrasound, revealed no other associated abnormalities.

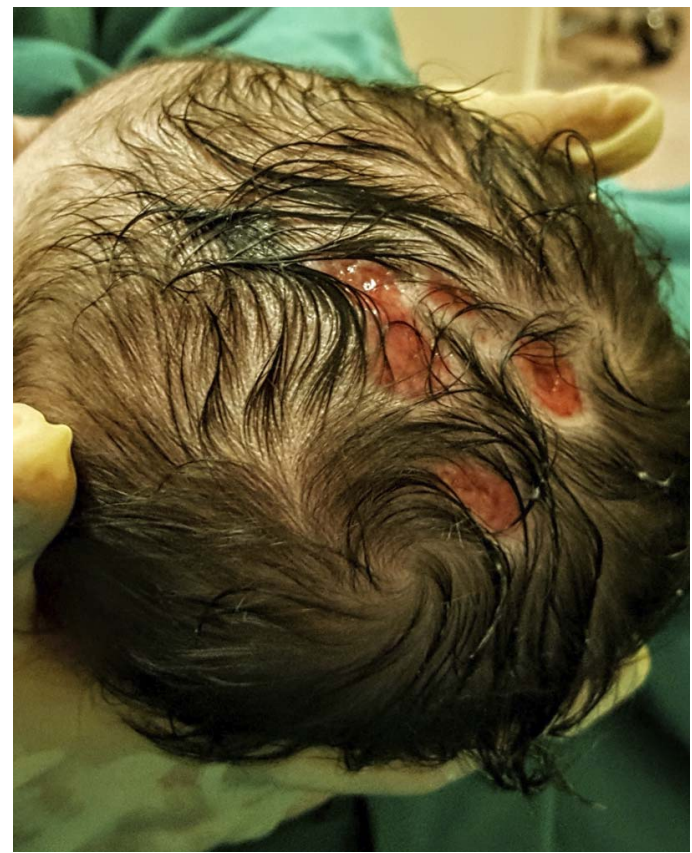

Figure 3 Areas of aplasia cutis congenita on the scalp. 


\section{Learning points}

- Amniotic band syndrome and aplasia cutis congenita are two unusual clinical entities with a variety of clinical presentations and an unclear underlying cause.

- Rupture of the amniotic membrane in an early pregnancy, forming amniotic bands, has been proposed as a cause of aplasia cutis congenita.

- Although aplasia cutis congenita often occurs as an isolated phenomenon, the presence of constriction rings seems to support the contribution of amniotic bands as a possible aetiology of aplasia cutis.
Contributors JP wrote the draft and conducted this publication. PL reviewed the manuscript. LR reviewed the manuscript and supervised the patient management. JP also was responsible for the patient orientation.

Competing interests None declared.

\section{Patient consent Obtained.}

Provenance and peer review Not commissioned; externally peer reviewed.

\section{REFERENCES}

1 Crum CP, Laury AR, Hirsch MS, et al. Amniotic bands. In: Crum CP, Laury AR, Hirsch MS, et al. eds. Gynecologic and obstetric pathology. Philadelphia, PA: Elsevier; 2016:776-7.

2 Mahajan M, Sharma P, Gupta S, et al. Amniotic band syndrome: a rare occurrence. JCR 2014;4:308-12.

3 Duan $X$, Yang GE, Yu D, et al. Aplasia cutis congenita: a case report and literature review. Exp Ther Med 2015;10:1893-5.

Copyright 2017 BMJ Publishing Group. All rights reserved. For permission to reuse any of this content visit http://group.bmj.com/group/rights-licensing/permissions.

BMJ Case Report Fellows may re-use this article for personal use and teaching without any further permission.

Become a Fellow of BMJ Case Reports today and you can:

- Submit as many cases as you like

- Enjoy fast sympathetic peer review and rapid publication of accepted articles

- Access all the published articles

- Re-use any of the published material for personal use and teaching without further permission

For information on Institutional Fellowships contact consortiasales@bmjgroup.com

Visit casereports.bmj.com for more articles like this and to become a Fellow 